\title{
Methodological Naturalism and the Truth Seeking Objection
}

\author{
Dr. Rope Kojonen \\ University of Helsinki \\ Faculty of Theology
}

\begin{abstract}
Methodological naturalism, the exclusion of the supernatural from the natural sciences, has drawn critique from both proponents of Intelligent Design and some philosophical naturalists who argue that the methods of science can also be used to evaluate supernatural claims. One principal objection to methodological naturalism has been what I call the truth seeking objection. In this article I develop an understanding of methodological naturalism capable of answering the truth seeking objection. I further also argue that methodological naturalism as a convention of science can be best defended by abandoning scientism. In this way methodological naturalism can be reconnected to the original theistic context in which it was first developed.
\end{abstract}

\section{Introduction}

Methodological naturalism as a ground rule of science has been one of the primary arguments against Intelligent Design (ID) and creationism. For example, in the 1987 trial in the U.S. over the teaching of creationism, philosopher Michael Ruse referred to methodological naturalism to criticize the efforts of creationists to portray creationism and evolution as competing scientific theories. Ruse claimed that no theory that appeals to supernatural entities can possibly be science, already by definition: "any reliance on a supernatural force, a Creator intervening in a natural world by supernatural process, is necessarily not science." ${ }^{1}$ In the verdict, five main criteria of science were defined, following Ruse: (1) Science is guided by natural law, (2) it explains by reference to natural law, (3) it is testable against the empirical world, (4) its conclusions are tentative, and (5) it is falsifiable. (Ruse 2009, 272; see further Pennock \& Ruse ed. 2009; Pennock 2011.) In 2005, in the Kitzmiller trial over the teaching of Intelligent Design in public schools, Judge

\footnotetext{
${ }^{1}$ In this article I will use the terms "natural" and "supernatural" as they are commonly used in the discussion over methodological naturalism. However, it is important to note that many theologians would object to the use of the term "supernatural". For example, Conor Cunningham $(2010,177)$ argues that we might rather call God natural, and nature supernatural. On the origin of distinction between the natural and the supernatural, see Bartlett 2008.
} 
John E. Jones similarly ruled that ID “violates the centuries-old ground rules of science by invoking and permitting supernatural causation." (Jones 2005, 64) Sometimes critics of ID have stated the scientific restriction of the supernatural very strongly: "even if all the data point to an intelligent designer, such an hypothesis is excluded from science because it is not naturalistic. Of course the scientist, as an individual, is free to embrace a reality that transcends naturalism." (Todd 1999) On this received understanding, science is simply by definition a search for natural explanations. Science is concerned with understanding the natural causal structure of the cosmos, and its methods are unsuited for discussing theological and philosophical questions, such as whether nature is ultimately purposeful or not.

However, methodological naturalism as an argument against ID has also recently faced critique. Unsurprisingly, the critique of methodological naturalism is common feature of the ID movement's argumentation. (Beckwith 2003) For its defenders, ID is revolutionary new science, and its opposition is merely ideological. The conclusion that nature is designed is argued to be the clear result of the cumulative efforts of the various natural sciences, and proponents of ID believe this conclusion to be 'so unambiguous and so significant that it must be ranked as one of the greatest achievements in the history of science'. (Behe 2006, 232-233) The critique of methodological naturalism regarding the study of life's history predates the ID movement (see e.g. Thaxton, Bradley \& Olson 1984, pp. 202-214). The critique of methodological naturalism made by later ID proponents traces back to Phillip E. Johnson, the early visionary of the ID movement. According to his critique, methodological naturalism hinders the capacity of science to find out truths and avoid false theories about nature. Johnson argued already in his Darwin on Trial that defenders of naturalism "enforce rules of procedure that preclude opposing points of view." (Johnson 1993, 118) By allowing only natural explanations within science, the possibility that biological life has actually been created supernaturally has been excluded from science already before the consideration of evidence, Johnson argues. He claims that this protects naturalism from falsification and critique, and compromises science as a search for true theories. The same objection to methodological naturalism has also been defended in various ways by thinkers outside the ID movement, such as Alvin Plantinga (1997) and Bradley Monton (2009). I call this the truth seeking objection to methodological naturalism. Johnson and the ID movement are confident that if the evidence were discussed openly, without prejudging the conclusion due to methodological naturalism, then ID's claims about nature would be vindicated. 
More surprisingly, methodological naturalism has also faced critique from some thinkers who do not think there is any plausibility to ID's arguments regarding the designedness of life. The critique concerns the specific understanding of methodological naturalism as a principle barring the consideration of supernatural hypotheses. In their article "How Not to Attack Intelligent Design Creationism" (2010) philosophers Maarten Boudry, Stefaan Blancke and Johan Braeckman argue that this kind of intrinsic methodological naturalism - where consideration of the supernatural is thought to be excluded already based on the definition and basic methodological assumptions of the natural sciences - is flawed, and none of the reasons for excluding the supernatural from science already in principle work. They further argue in their article "Grist to the Mill of Anti-Evolutionism: The Failed Strategy of Ruling the Supernatural Out of Science by Philosophical Fiat" that methodological naturalism of this type invites the criticism that science is biased against design, since it appears to exclude supernatural explanations without consideration. (Boudry, Blancke \& Braeckman 2012) Instead, they present a pragmatic defense of methodological naturalism: the restriction of science to the natural should be done provisionally and based on the previous failure of supernatural explanations and the success of naturalistic explanations. This means that science should in principle be open also to supernatural explanations and the ID proponent's arguments; they are rejected only because of their failure, not because the idea of design is itself outside the bounds of the natural sciences.

Nevertheless, this kind of expansion of the understanding of methodological naturalism is not easy for all to accept. Is it truly so that supernaturalistic personal explanations could in principle be a part of the natural sciences? Within pragmatic methodological naturalism, the rejection of supernatural explanations from the natural sciences is based on the failure of such explanations in all instances in history. This defense of methodological naturalism should be compelling particularly for philosophical naturalists, who do not see any good reason to believe in a Creator God, and who thus think there is good reason to believe that all of reality is amenable to scientific study in so far as it can be studied at all. (Ritchie 2008; see further Williams \& Robinson 2014) However, as I will argue below, it does not fit the original theistic context of the development of methodological naturalism, because the developers of methodological naturalism believed in the goodness of at least some theistic explanations. 
In the contemporary situation there still also exist many people who think that supernatural (or theistic) explanations can sometimes be good, without thinking that these explanations should therefore be considered to be a part of science. Rather, the arguments for and against the existence of God are defended as philosophical arguments, not as part of the natural sciences. Richard Swinburne, for example, argues that natural theology (the attempt to support belief in God with some publicly available evidence) is based on phenomena which are either "too big" or "too odd" for science, such as the origin of the natural laws. (Swinburne 2004, 74-75; see further Craig \& Moreland 2012 and Manning, Brooke \& Watts (eds.) 2013). ${ }^{2}$ Though religious belief in God is not usually adopted merely as an explanation, it does for many also have an explanatory dimension. (Vainio 2010, McGrath 2016). For anyone accepting even some supernatural explanations as probably true, the idea of the general failure of supernatural explanations cannot function as the grounding of methodological naturalism within science. So, it seems to me that people who agree with Swinburne or other natural theologians must seek some other grounds for methodological naturalism, and some other way of defending methodological naturalism against the truth seeking objection. Theists will be much more attracted to traditional intrinsic methodological naturalism, which allows the acceptance of methodological naturalism as a convention of the natural sciences, while leaving us "free to embrace a reality that transcends naturalism" (Todd 1999) outside the natural sciences. That is, theists are more apt to be interested in methodological naturalism without scientism, the belief that science is our only reliable guide to reality. (Stenmark 2001; Williams \& Robinson, ed. 2014) It seems prudent to study whether this kind of traditional methodological naturalism can withstand the critique proponents of Intelligent Design have launched against it, and on what conditions methodological naturalism can indeed be a reasonable ground rule of the natural sciences.

The purpose of this article is to develop the truth seeking objection against methodological naturalism further and to analyze how methodological naturalism can be formulated to respond to this objection. To that end, I will begin by analyzing the critique of methodological naturalism within the ID movement, concentrating particularly on the truth seeking objection. I will then

\footnotetext{
${ }^{2}$ For critical evaluations of theistic explanations, see Mackie 1982, Dawes 2009 and Philipse 2012. For analysis of the related question of the "God of the Gaps", see Kojonen $2016 \mathrm{~b}$.
} 
develop a response to the truth seeking objection, using insights from both the philosophy of science and from the academic discussion regarding the relationship of theology and the natural sciences.

\section{The Critique of Methodological Naturalism in the Intelligent Design Debate}

As Boudry, Blancke and Braeckman $(2010,228)$ note, the basic critique of methodological naturalism predates the contemporary Intelligent Design movement, and was already presented by creationists like Duane Gish, who wrote that the "reason that most scientists accept the theory of evolution is that most scientists are unbelievers, and unbelieving, materialistic men are forced to accept a materialistic, naturalistic explanation for the origin of all living things." (Gish 1973, 24) Nevertheless, the critique of methodological naturalism is much more pronounced in the ID movement's argumentation. Johnson's key argument, first stated in his "Darwin on Trial" (1993[1991]) was that in some cases, particularly in the case of evolutionary biology, the evidential standards of science have been subverted by methodological naturalism. (Ratzsch 2002) Johnson argued that if we limit the scope of our search for explanations a priori, then it may well be that we end up setting our search parameters in such a way that the correct explanation is not even considered. According to Johnson, this is just what has happened with Darwinian evolutionary theory, which he claims is only weakly supported by the evidence. According to Johnson, evolutionary theory can only be called the best scientific explanation of the origin of the species because design is ruled out a priori. If Darwinism was not protected by such a philosophical assumption, then it would quickly crumble. (Johnson 1993, chapter 9)

While Johnson's early argumentation in Darwin on Trial critiqued the way methodological naturalism bars supernatural design from science (Johnson 1993, chapter 9), later ID writings have emphasized that design can be detected without knowing anything about whether the designer is supernatural or not, and without reliance on prior religious beliefs. (Luskin 2008) Thus the design argument in biology is argued to be analogous to forensic science, archeology and the SETI-project, where the actions of intelligent designers may be detected without referencing the supernatural. Critics of ID argue, however, that ID's designer is most plausibly identified as supernatural, since 
this designer is also argued to be responsible for things like the fine-tuning of the laws of nature. (Russell 2005, Sober 2007) Indeed, while proponents of ID argue that identifying the designer as supernatural is a separate logical step beyond the design argument, the most prominent defenders of ID such as Johnson, Michael J. Behe (2006, 251), William A. Dembski (2004, chapter 25) and Stephen C. Meyer $(2009,428-430)$ all believe that the designer is most plausibly the Triune Christian God. (See further Kojonen 2016a, chapter 6)

This explains why critics of ID believe that ID violates methodological naturalism as a restriction against supernatural explanations in science. However, why do proponents of ID believe that ID violates methodological naturalism? The answer seems to be that as proponents of ID nowadays adopt a somewhat different definition of methodological naturalism than Johnson. For instance, Meyer argues that "Methodological naturalism asserts that to qualify as scientific, a theory must explain all phenomena by reference to purely material - that is, non-intelligent-causes." (2009, 434) As Kathryn Applegate $(2013,40)$ notes, here methodological naturalism is understood to bar not just supernatural designers, but also all finite intelligent designers. Sometimes later ID texts indeed agree with methodological naturalists in arguing that supernatural factors should be barred from science. Thus William Dembski and Jonathan Wells assert in the ID textbook The Design of Life that "supernatural explanations invoke miracles and therefore are not properly part of science. Explanations that call on intelligent causes require no miracles but cannot be reduced to materialistic explanations." (2008,13-14) Dembski's position is that ID's design argument as such does not take a stance of whether the designer is supernatural or non-supernatural. However, even if the only possibility is that the designer is "non-embodied" (which sounds supernatural) Dembski still argues that this kind of implication alone should not make the design argument unscientific. (2004, 191; 2002, pp. 347-353; similarly Behe 1998, 34-35) The critique of methodological naturalism remains a distinctive emphasis of ID's argumentation, repeated in all major defenses of ID.

The standard definition of methodological naturalism does not include a ban on all design-based explanations, just supernatural ones. However, the interpretation that methodological naturalism also rules out non-supernatural intelligent causes from the natural sciences is not unreasonable when compared to the definition of science in the 1987 creationism trial. Design-based explanations are fundamentally different from law-based explanations. The testing of personal 
explanations by scientific experiments seems challenging, because it is much more difficult to generate precise testable predictions from a hypothesis of design, though it may be possible in some cases. As Del Ratzsch notes, "design theories are, ultimately, theories involving agency. And, with respect to agents, theories and explanations often must trail data. We are often in positions of utter inability to predict specific human actions, but such actions once observed may be readily and quite legitimately explainable." (Ratzsch 2001, 117) Personal explanations are in many ways quite different from explanations that are usually considered in the methodologically naturalistic natural sciences, though they may be used in other sciences, such as psychology, sociology, forensic science, archeology and SETI. (Swinburne 2004, chapter 2). This provides some justification for the idea that personal explanations are also excluded from the natural sciences. So, both critics and defenders of ID have their separate justifications for the idea that methodological naturalism bars the consideration of design within natural science.

In contrast to methodological naturalism, Johnson proposed an alternative "theistic realist" framework for science. This theistic realism would be an open investigation of nature, allowing that God has created nature in an orderly fashion to be studied scientifically. In natural history, God could have used evolutionary mechanisms, or he could have acted miraculously. Johnson has a strong theological preference for any option which allows us to have evidence of divine action in history. However, neither evolution nor creationism is to be barred from science on a priori grounds (as Johnson believes is done in methodological naturalism), but only on the basis of empirical investigation. (Johnson 1993, chapter 9; Johnson 1995, appendix) ${ }^{3}$

\section{Developing the Truth Seeking Objection}

The basic point of the truth seeking objection can also be formulated without the theological framework which assumes that God is free to create in any way. Methodologically naturalistic science seeks only natural causes to explain for natural history. None of its theories about natural history can include any reference to a supernatural creator or purposes behind life. But let us

\footnotetext{
${ }^{3}$ Johnson's theistic realism is related to the idea of theistic science, according to which Christian believers should conduct science from the standpoint of assuming that God exists, taking into account all that they believe as Christians. On this discussion see Ratzsch 2004 and Labody 2015 (defending theistic science) as well as Stenmark 2004, chapters 8 and 9 (defending the neutrality of science).
} 
suppose that the natural history is in actual fact explained by the actions of a supernatural Creator, working beyond the laws of nature to affect the world. Suppose further that natural processes would have actually been incapable of producing the various forms of life we see around us. But even supposing that this is factually the case and that we have plenty of evidence to confirm it, methodologically naturalistic science could never discover these essential truths about the history of life. Rather, for methodologically naturalistic science, the best explanation of the origin of life would even in this case be that the various forms of life emerged as the result of some kind of evolutionary processes which we do not yet understand. In such a world, using methodologically naturalistic natural science as our guide to reality would lead us to form highly erroneous beliefs. This would be counter to the usual pursuit of testability and reliability in science. Or so the argument goes. ${ }^{4}$

Below, I have outlined the argument with premises:

1. Science aims at generating theories and models that are as close to true as possible about the world. ${ }^{5}$

2. The methodology of science should be chosen in such a way as to make attaining this goal as likely as possible.

3. If the true explanation of natural history is not naturalistic, then methodological naturalism would hinder science from attaining its goal of finding true explanations.

4. It is in principle a credible possibility that the true explanation of natural history is not naturalistic, but rather supernatural.

5. Therefore, methodological naturalism might hinder science from finding out the truth about natural history.

6. Therefore, methodological naturalism conflicts with the goals of science.

7. Therefore, methodological naturalism should be abandoned.

One way to critique the argument would be to focus on premise 4: that supernatural creation or intelligent design is a credible possibility that should be taken into account when considering what the true explanation is. It might be argued that there are lots of hypotheses that we do not take into

\footnotetext{
${ }^{4}$ Monton (2013) puts the point as follows: "If science really is committed to methodological naturalism, then it automatically follows that the aim of science is not generating true theories. Instead, the aim of science would be something like: generating the best theories that can be formulated subject to the restriction that those theories are naturalistic."

${ }^{5} \mathrm{I}$ am assuming a critical realist understanding of the nature of science here. This is the assumed philosophy of most working scientists, but not uncontroversial in the philosophy of science. (See Niiniluoto $2002 \&$ McGrath 2002 for more on this discussion.) If we adopt a different, antirealist understanding of the goals of scientific theories, then the truth seeking objection does not work, at least without heavy modification.
} 
account in natural science. For example, natural scientists do not usually have to consider the possibility that we are actually living inside the Matrix. There is no need to require the sciences to take into account possibilities that cannot be investigated and for which we do not (or in some cases even cannot) have evidence.

Indeed there are philosophical and theological worldviews in which premise 4 does not have much credibility. These may even be dominant in parts of contemporary Western culture: as Charles Taylor has noted in his often quoted analysis of secularism, for many the idea of God acting in the world has become difficult to conceive of as a plausible possibility. (Taylor 2005, 141) However, there are also cultures in which premise 4 is at least credible enough to deserve consideration. Of course, the idea that life is created is also part of the religious traditions of Judaism, Christianity and Islam. It is true that God is also thought to work through secondary causes, so that there is no necessity to suppose supernatural action within natural history. But the supernatural nature of creation has also been a widely accepted view in these traditions, so it does seem like a theologically plausible possibility without further evidence. ${ }^{6}$ One problem with all of this is that if we rely on these ideas to ground or deny methodological naturalism, we need to introduce a lot of theological background assumptions to ground the practices of the natural sciences.

There may also be reason to take the possibility of supernatural design seriously for those outside religious traditions. Both critics and defenders of creationism and ID usually agree that biological order bears the appearance of having been designed for a purpose. The intuitive credibility of design as an explanation is a commonly stated background assumption of the ID movement. Behe argues that "the overwhelming appearance of design strongly affects the burden of proof: in the presence of manifest design, the onus of proof is on the one who denies the plain evidence of his eyes." $(2006,265)$ In recent decades, the idea that humans intuitively see nature as designed has received support from research in the cognitive science of religion. Teleological explanations are argued to be natural to us humans in the sense that they accord with our natural cognitive tendencies, and so are easy for us to accept. Some even argue that children are "intuitive theists". Even adults appear to have the same intuitive tendency to explain things by reference to purposes. (Kelemen 2004; see further De Cruz \& De Smedt

\footnotetext{
${ }^{6}$ It is possible to argue that while this is a serious possibility (and so premise 4 is credible), it is not a scientific hypothesis, but a theological and philosophical idea which is not in competition with scientific explanations such as evolution. I will come back to this below.
} 
2015) As Ratzsch and Koperski (2015) put the point, "design thinking may be natural to our sorts of intellects". As stated, even many critics of the design argument usually also see it as intuitively plausible. ${ }^{7}$

Based on the commonality of this kind of experience of nature, it seems that design is indeed an explanation of nature that is initially appealing to many, perhaps to most humans. It therefore seems possible to argue that it would be strange to completely ignore such an intuitive plausible explanation when investigating the history of life. So, it seems to me that the truth seeking objection deserves to be taken seriously. We need to show how methodological naturalism does not actually lead away from the truth.

A common way to answer the ID movement's critique of methodological naturalism theologically has been to make the distinction between methodological and metaphysical naturalism. (Murphy 1993, Pennock 1999). This distinction was already present in what appears to be the first article using term "methodological naturalism." ${ }^{8}$ In his article "Naturalism in the natural sciences" (1986), Wheaton College philosopher Paul de Vries introduced the term "methodological naturalism" to describe the convention that the natural sciences are limited to the study of natural causes and natural laws, and that no references to supernatural factors should be made within science. De Vries argued that methodological naturalism is distinct from metaphysical naturalism which is a philosophical belief that nothing supernatural (such as God, gods, spirits or souls) exists. De Vries' point was that it is both possible and reasonable to hold to methodological naturalism within the natural sciences without believing in metaphysical naturalism. ${ }^{9}$

\footnotetext{
${ }^{7}$ Here's a quote illustrating this from David Hume's "Dialogues Concerning Natural Religion", spoken in part III by the character Cleanthes:
}

"Consider, anatomize the eye; survey its structure and contrivance; and tell me, from your own feeling, if the idea of a contriver does not immediately flow in upon you with a force like that of sensation. The most obvious conclusion, surely, is in favour of design; and it requires time, reflection, and study, to summon up those frivolous, though abstruse objections, which can support Infidelity. Who can behold the male and female of each species, the correspondence of their parts and instincts, their passions, and whole course of life before and after generation, but must be sensible, that the propagation of the species is intended by Nature? Millions and millions of such instances present themselves through every part of the universe; and no language can convey a more intelligible irresistible meaning, than the curious adjustment of final causes. To what degree, therefore, of blind dogmatism must one have attained, to reject such natural and such convincing arguments?"

${ }^{8}$ See Numbers 2003 for the history.

${ }^{9}$ De Vries 1986. Many different motivations for strong methodological naturalism have been posited. ID proponents Dembski and Witt (2010, 23-24) argue that the main motivation of methodological naturalism is atheism: "Only about one in ten Americans is an out-and-out atheist, but atheists have managed to extend their influence by selling religious 
Del Ratzsch (2002) argues that whether or not Johnson has adequately understood the difference between methodological and metaphysical naturalism, the core of his critique stands: "If (perhaps for overwhelmingly good reasons) science is restricted (even just methodologically) to 'natural' explanatory and theoretical resources, then if there is a supernatural realm which does impinge upon the structure and/or operation of the 'natural' realm, then the world-picture generated by even the best science will unavoidably be either incomplete or else wrong on some points." Johnson's argument is that methodologically naturalistic science will reliably lead to true beliefs about the history of life only if that history actually is purely naturalistic. But there is no a priori way to know that the history of life is truly naturalistic; it is in principle possible that the history of life actually includes a supernatural creation event or several such events. This possibility needs to be eliminated only after considering the evidence. Johnson's claim is that methodologically naturalistic science cannot consider the evidence impartially, since it cannot consider any non-naturalistic possibilities. The distinction between methodological and metaphysical naturalism indeed does not seem to affect this point.

\section{Provisional Methodological Naturalism as a Response to the Truth Seeking Objection}

One way of responding to the truth seeking objection would be to adopt the pragmatic, provisional understanding of methodological naturalism stated by Boudry, Blancke and Braeckman (2010). Under this understanding of methodological naturalism, supernatural design can in principle be considered as an explanation within the natural sciences. The rejection of design is then based on the evidence, not on any a priori considerations. This basic position has also been stated by others: For example, Phillip Kitcher (2007) argues that ID does qualify as science, and that even methodologically naturalistic science can be open to evidence of design.

people a related idea called methodological materialism." (Similarly Bartlett \& Holloway (eds.), forthcoming) Prior belief in metaphysical naturalism would indeed be one possible way of grounding methodological naturalism. If it seems likely that nothing supernatural exists, then this also makes it reasonable not to refer to supernatural entities within the natural sciences. However, as noted, to make methodological naturalism appealing to people other than those who are already committed to philosophical naturalism, some other grounds would be needed. Also, as I note in the main text, methodological naturalism initially did not emerge as an atheistic idea, so it seems reasonable to think that its initial main motivation must have been compatible with theism. 
However, he goes on to argue that ID is bad $18^{\text {th }}$ century science which has been superseded and refuted by the developments of science after that. Niall Shanks similarly argues that "the methodological naturalist will not simply rule hypotheses about supernatural causes out of court", but rather based on the failure of supernaturalistic arguments. (2004, 141-142; similarly Sarkar $2011)^{10}$

In practice those professing the openness of the natural sciences to design-based explanations may still adopt criteria for evaluating explanations which make design based explanations in practice very difficult to defend. For example, Dawkins begins his book the Blind Watchmaker by affirming that intelligent design is an intuitively very plausible explanation for biological complexity. (Dawkins 1991, chapter 1) In his later book The God Delusion, Dawkins even calls God a "scientific hypothesis" (2006, chapter 1), one that the progress of science has made unnecessary by providing better explanations. However, on closer examination, it is clear that for Dawkins, the rules of rationality themselves mitigate against the design argument and belief in God. At the end of the Blind Watchmaker (chapter 6) Dawkins considers the question of how the origin of life should be explained, and argues on philosophical grounds that even random chance is a better explanation for the origin of life than supernatural design. This is because, for Dawkins, the purpose of explanation is to understand the complex by referring to something less complex. The God hypothesis, according to Dawkins, postulates a very complex Creator to explain the complexity of the biological world and the order of the universe. Thus Dawkins (2006, chapter 4) argues that the God hypothesis doesn't really explain complexity, but only introduces more complexity.

\footnotetext{
${ }^{10}$ This type of rejection of a priori arguments against ID is also implicit in some accounts in which the rise of Darwinian evolutionary theory is seen as the central reason why biological design arguments can now be rejected. For example, cosmologist Sean M. Carroll $(2003,631)$ writes that "A few centuries ago, for example, it would have been completely reasonable to observe the complexity and subtlety exhibited in the workings of biological creatures, and conclude that such intricacy could not possibly have arisen by chance, but must instead be attributed to the plan of the Creator. The advent of Darwin's theory of evolution, featuring descent with modification and natural selection, provided a mechanism by which such apparently improbable configurations could have arisen via innumerable gradual changes." This implies that without Darwinian evolutionary biology, design would still be the best explanation for biological order. This assumes that design possesses at least some rationality as an explanation and cannot be dismissed on a priori grounds, just by invoking the definition of science. In my understanding, proponents of ID would welcome this kind of understanding of methodological naturalism, but would just differ on the state of the evidence. There has been some debate whether Hume or Darwin was more important in refuting biological design arguments. Historically, biological design arguments continued to be defended long after Hume, and indeed Paley's Natural Theology was written only after Hume. Gregory Dawes (2007) argues that Darwin is indeed necessary, as Carroll says. Walhberg (2012) goes further and argues that biological design arguments are even compatible with Darwinian evolutionary biology.
} 
Dawkins'argument has been subjected to extensive and good critique. (E.g. Orr 2007, Plantinga 2007, Glass 2012). But here my point is simply that on Dawkins' philosophy of explanations, the playing field is not really open to theistic or design-based explanations. Rather, the superiority of non-theistic explanations is already built into the premises of his system of thought. This is not really moderate methodological naturalism, since it is not actually open to other than naturalistic explanations. This kind of reasoning is vulnerable to the truth-seeking objection against methodological naturalism, so defending moderate methodological naturalism requires changing the ground rules of science so that they do not include a built-in preference for natural explanations. This means expanding the traditional understanding of "natural science."

However, it may be desirable to retain science as an enterprise focused just on natural explanations, so that its basic features are more easily defined and the difference between personal explanations and natural science is maintained. This would allow the natural sciences to focus on those explanations which are "scientifically tractable" (Collins 2006), leaving other kinds of explanations for other disciplines. ${ }^{11}$ Some observers of the ID debate have criticized the actual criteria of demarcation used to rule the supernatural outside the natural sciences. This discussion was begun by philosopher of science Larry Laudan already after the McLean v. Arkansas creationism trial (see Pennock \& Ruse ed. 2009). One problem is also that the core of theories can seldom be falsified directly: theories can often be amended to explain anomalies, and tests require the addition of auxiliary hypotheses to the theory. Perhaps creationism and ID could also be formulated to be testable at least to some extent. (Boudry, Blancke \& Braeckman 2010; Ratzsch 2001, chapters 7-9; Koperski 2008) The problem of demarcating between science and pseudoscience is a difficult one, and there is "almost complete disagreement on the general criteria" by which this demarcation is to be done. (Hansson 2015) ${ }^{12}$ Nevertheless, though vagueness in definitions can often be unavoidable, we can typically operate well in spite of it (van Deemter 2010). We can usually quite easily tell if a problem is better studied through the methods of sociology than through the methods of chemistry, for example. Perhaps there might be similar reasons for

\footnotetext{
${ }^{11}$ For the contrary perspective that design-based explanations are in all relevant respects similar to natural scientific explanations, see Meyer 1999.

12 Nagasawa (2011, 97-101) also notes that it is for ID critics a much easier strategy to argue that Intelligent Design has not been established as good science, than to argue that it could not even in principle be scientific. See Nagasawa (2011, 97-101).
} 
thinking that the natural sciences should be methodologically naturalistic, and putative supernatural explanations should be considered elsewhere.

\section{Defending Intrinsic, Provisional Methodological Naturalism}

I will now argue that looking at the original context for the development of methodological naturalism makes the truth seeking objection much less persuasive. Historians Ronald C. Numbers (2003) and Robert C. Bishop (2013) trace the origins of methodological naturalism to the Christian Middle Ages. Because Christians believed in a God who had created a rational universe, they also believed that the causal structure of that universe could be understood through studying it. The aim of the natural sciences from the scientific revolution onwards was simply to focus on studying the inner workings of and mechanisms of God's creation, rather than the purposes of God. Interestingly, typically Christian natural philosophers and early modern scientists affirmed the reality of even miraculous divine action. Thus their methodological naturalism, such as it was, was certainly not based on the general failure of supernatural or theistic explanations in all instances. Rather, methodological naturalism was based on pragmatic reasons. By focusing on natural explanations, scientific methods could be formulated to study them as accurately as possible. As Bishop $(2013,13)$ notes: “for these natural philosophers, MN [methodological naturalism] was a commitment to particular methods of inquiry for a particular limited purpose: To understand the nature of the matter, forces, and laws that God had made."

Contemporary theistic defenders of methodological naturalism also typically understand methodological naturalism in the same way as not excluding theistic explanations completely. In the theology and science community, the natural sciences, the humanities, as well as theology and philosophy are understood to each have their own domain. Each science proceeds by its own method to study those questions which its methods are best suited for analyzing. The proper methods of investigation are based on our understanding of the ontology of what is being studied. There can be overlap and connections between the different fields, but by and large each science does its own thing. (Russell 2008; see also Peacocke 1993, 217 Alister E. McGrath has used Roy Bhaskar's (1998) concept of a "stratified reality" to argue that studying the complexity of reality requires several different levels of explanation. (McGrath 2002; McGrath 2016) Theistic explanations 
are accepted within these models. For example, Christian believers can believe that God is the proper explanation for the fine-tuning of the laws of nature (Collins 2012; Leslie 1989). However, theistic explanation is typically understood to work on a different level and in a different manner than explanations in the natural sciences. For example, John F. Haught $(2008,35)$ argues that theology should have "the role of ultimate explanation in an extended hierarchy of explanations that includes, and does not in any way compete with, scientific accounts." Accordingly, the critique of the "God of the gaps" is also influential in the discussion over theology and the natural sciences. It is argued that we should not insert divine action into gaps of scientific knowledge, but let theological explanation remain on the level of ultimate explanation. (See further Kojonen 2016b)

Although this basic understanding of the relationship of theology and the natural sciences may help promote mutual understanding between disciplines, one might still press the truth seeking objection against it. Yes, the idea that God acts through secondary causes is a commonplace in traditional Christian theology. Nevertheless, the traditional view also includes the possibility of miracles. Thomas Aquinas did argue that God acts through secondary causes, but he did also believe that "by no other means can it better be made manifest that all nature is subject to the divine will, than by the fact that He sometimes works independently of the order of nature." (Summa Contra Gentiles, bk. 3, ch. 99). ${ }^{13}$ So, one might argue that there is no way to be sure a priori that God acts only through secondary causes in the history of life, and that this history thus did not include any supernatural creative acts. As Plantinga $(1997,16)$ writes, “Obviously we have no guarantee that God has done everything by way of employing secondary causes, or in such a way as to encourage further scientific inquiry, or for our convenience as scientists, or for the benefit of the NSF."

The same basic idea of the freedom of God also underlies Johnson's (1995) theistic realism. Johnson's emphasis on the independence of God from the world and his ability to create any sort of world is reminiscent of the medieval debates on the logic of "possible worlds". Pierre Duhem dates the beginning of the scientific revolution at March 7, 1277, when a set of theses of Aristotelian physics was condemned as wrongfully imposing limits on God's omnipotence. Duhem argued that this lead to the rise of empirical science, because now Christians could not discover how God had created the world based just on philosophical first principles, but had to rely on empirical observations and

\footnotetext{
${ }^{13}$ Translation from Aquinas (1997, 197). On Aquinas' position, see Silva (2014, 13-14) and Sollereder (2015).
} 
experiments. (Koons 2003, 80.) The truth-seeking critique of methodological naturalism seeks to apply this same reasoning also to methodological naturalism. Plantinga $(1997,16)$ argues the point as follows: "We have no good grounds for insisting that God must do things one specific way; so far as we can see, he is free to do things in many different ways. So perhaps he did create human life specially; or perhaps she has done other things specially. We can't properly rule this out in advance by way of appeal to speculative theology; we should look and see."14

I agree with Plantinga and Johnson that we do not have very strong theological grounds for assuming (before the evaluation of the empirical evidence) that God has not acted miraculously in the history of life. Nevertheless, I would argue that based on the aforementioned understanding of the relationship of the different disciplines, it is possible to defend intrinsic methodological naturalism against the truth seeking objection. But this can only be done if we reject the basic assumption that it is the job of the natural sciences to seek the truth about everything. The truth seeking objection assumes that science is our guide to reality, but theistic defenders of methodological naturalism have argued from the beginning that there is also truth outside of the natural sciences. The natural sciences are assumed to study only a part of reality, particularly that part which can be understood by reference to purely natural laws and mechanisms. Philosopher Hans Halvorson (2014) thus argues in his defense of methodological naturalism that the truth seeking objection makes an "unwarranted jump from the fact that science is trying to discover truths, to the claim that science is trying to discover all sorts of truths. But some people, in particular theists, might think that some truths aren't amenable to scientific investigation." If we recognize that science is not the only way to know, then there is no reason why methodological naturalism should necessarily lead us astray. Rather, this account allows us to recognize when we encounter phenomena which are not amenable to methodologically naturalistic science. When we

\footnotetext{
${ }^{14}$ Some have argued that the value of the regularity of the cosmos makes it unlikely that God would act miraculously in nature without good reason. (See e.g. McDonald \& Tro, forthcoming). Thus one could argue that if there is no good reason to expect that God would have acted miraculously within natural history, then the Christian believer should expect to find that biological evolution happens through the effect of secondary causes which can be studied wholly by the natural sciences. One might also argue that the problem of natural evil requires assuming that God never intervenes in nature - otherwise we could easily ask why God does not intervene more. (On this discussion see especially Corabi 2009.) While these arguments are interesting, ultimately I do not think they are strong enough to allow us to rule the possibility of supernatural activity in natural history already without considering the empirical evidence. It is not impossible for defenders of supernatural design to think of some reason why God might have acted supernaturally. For example, McCullough (2013) argues that miracles in nature serve as a powerful testimony of the existence of a theistic (as opposed to deistic) God who takes a personal interest in life. See further Kojonen 2016a, chapters 9-10 \& Kojonen 2016b.
} 
reject scientism - the belief that science is the only way to gain reliable knowledge - we can accept Halvorson's point that natural science is not trying to discover all sorts of truths. (Stenmark 2001; 2004)

Suppose that the history of life indeed includes supernatural creation events, and that this cannot be discovered through the natural sciences. If we reject scientism, then the inability of the natural sciences to talk about the creation event does not mean that such a thing could not be thought about outside of the natural sciences. If we respect the idea that there are valid disciplines other than the natural sciences, then each question should belong to the domain of the discipline that can best study the question, though solving a problem might often require input from several different disciplines. On this kind of understanding, the inability of the natural sciences to refer to personal explanations is no more problematic than the inability of psychologists to study quantum mechanics. It may still be possible to defend belief in the designedness of the cosmos (and also even the designedness of biology, according to some) as an argument of natural theology, rather than a part of the natural sciences. ${ }^{15}$

So, on my understanding, there must always be something provisional about this methodological naturalism. This is because the proper limits of each discipline (such as chemistry, biology, psychology, philosophy, theology and so on) are not revealed infallibly in some holy writ, but must be based on our constantly developing understanding of the nature of reality and our experience of what methods work in understanding certain kinds of problems. So in this sense I would agree with Boudry, Blancke and Braeckman (2010) that methodological naturalism in explaining the phenomena of biology, for example, must be based on our experience that natural explanations tend to work quite well for biological phenomena. As Uskali Mäki (2013) argues, "scientific imperialism" as the intrusion of one discipline into what has traditionally been considered the domain of another science can in principle also be a recommendable thing. Sometimes, theories from one discipline of study can legitimately shed light on long-standing problems in another discipline. The success or failure of such attempts has to be evaluated on a case-by-case basis.

\footnotetext{
${ }^{15}$ See Wahlberg 2012 for the natural theological argument that perceiving biology as designed is compatible with evolutionary biology; see further also Kojonen (forthcoming) for an analysis of this argument strategy.
} 
The advent of evolutionary biology can be regarded as just such an event where a phenomenon that was previously widely thought to be the realm of theology (the origin of species) was transformed into the domain of the natural sciences. However, (and here I agree again with critics of methodological naturalism such as Boudry, Blancke and Braeckman 2010, 240-241) we can in principle imagine a world where the origin of life and the origin of species were actually caused by a supernatural creation event, no matter how credible or incredible this appears on our world. In such a world, I would argue, it might become reasonable to regard the origin of life or the origin of species as the proper boundary between theology and the natural sciences, or perhaps the domain of some new kind of biological science combining the methods of forensics, archeology and SETI (the Search for Extraterrestrial Intelligence) with the traditional methods of biology. In this case methodologically naturalistic science would no longer be the best science for studying the origin of life. So, I agree that something like ID could in principle be plausible in some possible world. ${ }^{16}$ So, even though this kind of methodological naturalism allows us to banish ID from the natural sciences, this does not mean stopping ID's arguments from getting a hearing. Nor would it mean that religious believers or philosophical naturalists could not use "all they know" to evaluate how likely some scientific hypothesis appears to be from the point of view of their worldview. ${ }^{17}$

Rather, the discussion comes down to how good the arguments for various views are, and in the end cannot be settled simply by reference to the traditional boundaries of disciplines (as valuable as these are). If we think that biological problems are properly a realm where strong methodological naturalism applies, we have to present arguments for why we think this is so, such as the appeal to the history of biological research and the success of evolutionary explanations. These arguments will have to show why it is likely that we will find naturalistic explanations for all biological problems, and why ID's arguments fail to overturn these naturalistic explanations. In the end, all depends on evidential considerations like our understanding of what kind of methods have previously been successful in solving each kind of problem. Our methodological choices

\footnotetext{
${ }^{16}$ For a similar pragmatic defense of methodological naturalism, see McDonald \& Tro (forthcoming). They do not consider methodological naturalism in the natural sciences to be a part of the definition of natural science as such, but argue that methodological naturalism is adopted in the natural sciences simply because of the past success of natural explanations.

${ }^{17}$ On how such evaluation could be done without compromising scientific neutrality regarding religion, see Stenmark 2004, chapters 8 and 9. For a competing point of view see Ratzsch 2004.
} 
should reflect our evidence-based understanding of the ontology of the problem. So, approaching some problem as an issue best suited to study by methodologically naturalistic natural sciences cannot in this defense be a dogmatically held position, but a working assumption and the result of the evaluation of our knowledge of that problem. In this conclusion I come close to the result of Boudry, Blancke and Braeckman, though I disagree somewhat with their overall motivation and model of methodological naturalism. ${ }^{18}$

The form of methodological naturalism outlined above holds that the natural sciences are by convention a search for natural causes. I have argued that this position is not made problematic by the truth seeking objection, as long as methodological naturalism is not coupled with scientism, where rationality and the possibility for knowledge about the natural world are restricted to the natural sciences. Together with scientism, methodological naturalism would indeed be the kind of ideological position that ID proponents criticize, because this would mean that the entire possibility of design-like explanations would be barred from consideration. In order to be defensible against the truth seeking objection, methodologically naturalistic science must in principle be able to have boundaries which are evidentially determined. In that case pragmatic reasons can lead to the adoption of methodological naturalism in the natural sciences. There is a boon here also for ID proponents: if they were to adopt this understanding of methodological naturalism, they could well present ID more as a way of challenging the mainstream understanding of where the boundaries of different disciplines lie, rather than as a violation of methodological naturalism as such.

\section{Conclusion}

\footnotetext{
${ }^{18}$ This conclusion also fits with Michael Ruse's definition of methodological naturalism as a necessary part of the natural sciences by definition. Ruse argues that "even if Scientific Creationism were totally successful in making its case as science, it would not yield a scientific explanation of origins. Rather, at most, it could prove that science shows that there can be no scientific explanation of origins." (Ruse 1982, 322; quoted in Plantinga 1997, 1). Thus Ruse is also not ruling out the possibility that creationists might be right a priori, but only based on what his (and the majority's) estimate of the scientific evidence is. If creationists or ID proponents were successful in making their arguments, then it would on the aforementioned understanding of methodological naturalism still not be natural science. However, in that case the domain of the natural sciences would be smaller than it is currently thought to be. This is not to say that the ID research program could not on this understanding also have parts that can be investigated within methodologically naturalistic science, such as the ID proponent's ideas about the limits of evolutionary processes. (See further Collins 2006).
} 
In the debate over ID, much energy has been used to debate whether ID can qualify as natural science or not. However, once we reject scientism, we should realize that there are also questions that are better studied by methods other than those typically used in the natural sciences. For example, methods of design detection are important in studying human culture and artifacts. The precise boundaries within disciplines are best based on our experience of what kinds of methods actually work in increasing understanding in each area. There is no a priori way to determine that methods of design detection could not in principle also provide the most understanding in problems like the origin of life; there is not even any a priori way to determine that the origin of life was not a supernatural miracle. The superiority of methodologically naturalistic science in investigating these problems needs to be argued, rather than assumed a priori. Because of this, intrinsic methodological naturalism will not ultimately allow us to avoid giving ID a hearing, if ID's arguments are otherwise good. After we take account of the truth seeking objection, methodological naturalism of any type should be defended non-dogmatically. Methodological naturalism must be, as Robert C. Bishop states, "an approach to scientific investigation that seeks to take phenomena on their own terms to understand them as they actually are." (Bishop 2013, 10) If intrinsic methodological naturalism is understood in this way as a provisional and non-dogmatic enterprise, the truth seeking objection does not refute it. This does not mean that there might not be some other reason for rejecting methodological naturalism as a part of the definition of natural science, of course. For example, one might continue to argue that methodological naturalism cannot be seen as a necessary part of the definition of natural science as long as the demarcation question remains unsettled. The socially accepted definition of natural science has undergone considerable development in history, and it could in principle do so again. ${ }^{19}$

However, once the question of truth is addressed, I would argue that the remaining questions about the definition of science are ultimately a side issue for the debate over ID and evolution. I agree with Susan Haack (2003) and Ian Hutchinson (2011) that the overt focus on the demarcation

\footnotetext{
${ }^{19}$ I have also not considered the arguments for "theistic science" at length in this paper. To develop the argument of this paper further, the definition of natural science as methodologically naturalistic would also have to be related to the discussion over the unity of science, dating back to medieval times. (On this see Cat 2014.) At some point we will probably want to integrate the results of the different sciences into a broader view of the world. Plantinga's theistic science as a rival to methodological naturalism is one method for attempting such an integration. (See Ratzsch 2004). Defenders of methodological naturalism will likely want to adopt a different method of integration, e.g. Russell's (2008) model of mutual creative interaction between different disciplines. See further also Stenmark 2004, chapters 8 and 9 .
} 
question in our intellectual culture reflects the cultural influence of scientism. Science has enormous cultural authority, and this makes it appealing for proponents of ID to attempt to claim the label "science" for their ideas, and for opponents of ID to argue that ID is merely pseudoscience. ${ }^{20}$ But in the long term, it would perhaps be prudent to question the undervaluing of non-scientific ideas in Western culture. If the problematic nature of scientism became more widely known, perhaps proponents and critics of ID would feel less pressure to argue about the definition of science, and could instead concentrate on more interesting questions, such as the evaluation of the arguments themselves. Methodological naturalism should also not be understood on a ban on discussing the theological and philosophical reasons that influence beliefs about origins. The quality of our arguments, the reliability of our conclusions and our ability to reason with others is far more important than the labels we give our arguments. ${ }^{21}$

\section{Bibliography}

Applegate, Kathryn. 2013. "A Defense of Methodological Naturalism." Perspectives on Science and the Christian Faith. Vol. 65. No. 1. 37-46.

Aquinas, Thomas. 1997. Basic Writings of Saint Thomas Aquinas. Volume Two: Man and the Conduct of Life. Ed. Anton. C. Pegis. Hackett Publishing.

Bartlett, Jonathan \& Holloway, Eric. Eds. Forthcoming. Naturalism and Its Alternatives in Scientific Methodologies. Toronto: Blyth Institute Press

Bartlett, Robert. 2008. The Natural and the Supernatural in the Middle Ages. Cambridge: Cambridge University Press.

Beckwith, Francis J. 2003. Law, Darwinism and Public Education: The Establishment Clause and the Challenge of Intelligent Design. New York, NY: Rowman \& Littlefield.

Behe, Michael J. 2006. Darwin's Black Box. 10th Anniversary edition. New York, NY: The Free Press.

\footnotetext{
${ }^{20}$ Dembski $(1998,26-27)$ explains that the emphasis is because science is the 'only universally valid form of knowledge in our culture'. From the side of ID critics, Quinn (2009) argues that "it is morally permissible for us to use the bad effective argument" if the complex truth is uneffective in opposing the idea that creationism could be science and thus could be acceptable for teaching in public schools in the U.S.

${ }^{21}$ Similarly, Petri Ylikoski $(2001,51)$ argues that "it is unclear why we should raise the issue of demarcation at all. An appeal to virtus dormitiva is a bad explanation outside science as well. We should be analyzing what makes explanations good in general. There are good explanations that are not scientific, and there are bad scientific explanations. It would be inconceivable, at least to me, if scientific and everyday explanations did not share some basic ideas about good and bad explanations. After all, science has its origin in common sense cognition. There should be some kind of continuity. Of course, it now includes much that is apparently incompatible with common sense, but I seriously doubt that this incompatibility also extends to the general principles of explanatoriness."
} 
1998. "Tulips and Dandelions \& A Response to Rebecca Fliestra” Books \& Culture: A

Christianity Today Review. September / October.

Bhaskar, Roy. 1998. The Possibility of Naturalism: A Philosophical Critique of the Contemporary Human Sciences. $3^{\text {rd }}$ Edition. (Critical Realism: Interventions). London: Routledge.

Bishop, Robert. C. 2013. "God and Methodological Naturalism in the Scientific Revolution and Beyond." Perspectives on Science and the Christian Faith. Vol. 65. No. 1. 10-23.

Boudry, Maarten; Blancke, Stefaan \& Braeckman, Johan. 2012. "Grist to the Mill of Anti-Evolutionism: The Failed Strategy of Ruling the Supernatural Out of Science by Philosophical Fiat." Science \& Education. Vol. 21. 1151-1165.

Boudry, Maarten; Blancke, Stefaan \& Braeckman, Johan. 2010. "How not to attack Intelligent Design Creationism: philosophical misconceptions about nethodological naturalism." Foundations of Science. Vol. 15. No. 3. 227-244.

Carroll, Sean M. 2003. "Why Almost All Cosmologists Are Atheists." Faith and Philosophy. Vol. 20. No. 5. 622-635.

Cat, Jordi. 2014. "The Unity of Science.” The Stanford Encyclopedia of Philosophy. Winter 2014 Edition. Ed. Edward N. Zalta. Available at <http://plato.stanford.edu/archives/win2014/entries/scientific-unity/>.

Collins, Robin. 2012. "The Teleological Argument.” The Blackwell Companion to Natural Theology. Eds. William Lane Craig \& J. P. Moreland. Malden, MA: Wiley-Blackwell.

2006. 'A Critical Evaluation of the Intelligent Design Program: An Analysis and a Proposal'. Home Page of Robin Collins. Available at <http://home.messiah.edu/ rcollins/Intelligent\%20Design/INTELL3.htm>. Accessed on 15 May 2013.

Corabi, Joseph. 2009. "Intelligent Design and Theodicy.” Religious Studies. Vol. 45. No. 1. 21-35.

Craig, William Lane \& Moreland, J. P. (eds.) 2012. The Blackwell Companion to Natural Theology. Oxford: Blackwell.

Cunningham, Conor. 2010. Darwin's Pious Idea: Why the Ultra-Darwinists and Creationists Both Get It Wrong. Grand Rapids, MI: Wm. B. Eerdmans.

Dawes, Gregory A. 2007. "What is Wrong with Intelligent Design?” International Journal for Philosophy of Religion. Vol. 61. No. 2. 69-81.

2009 Theism and Explanation. New York, NY: Routledge.

Dawkins, Richard. 1991. The Blind Watchmaker: How the Evidence of Evolution Reveals a Universe without Design. London: Penguin.

2006. The God Delusion. London: Bantam Press.

De Cruz, Helen \& De Smedt, Johan. 2015. A Natural History of Natural Theology: The Cognitive Science of Theology and Philosophy of Religion. Cambridge, MA: The MIT Press.

Deemter, Kees van. 2010. Not Exactly: In Praise of Vagueness. Oxford: Oxford University Press.

Dembski, William A. 2004. The Design Revolution: Answering the Toughest Questions About Intelligent Design. Downer's Grove, IL: Intervarsity Press. 
Intelligence. Lanham: Rowman \& Littlefield Publishers.

1998. "Introduction: Mere Creation". Mere Creation: Science, Faith and Intelligent Design. Ed. William A. Dembski. Downers Grove, IL: InterVarsity Press.

Dembski, W. \& Wells, J. 2008. How to be an Intellectual Fulfilled Atheist (Or Not). Wilmington, DL: Intercollegiate Studies Institute.

Dembski, William A. \& Witt, Jonathan. 2010. Intelligent Design Uncensored. Downers Grove, IL: InterVarsity Press.

De Vries, Paul. 1986. "Naturalism in the Natural Sciences," Christian Scholar's Review, 15, 388-396.

Gish, Duane T. (1973). Evolution: The fossils say no!. San Diego: Creation-Life Publishers.

Glass, David H. 2012. “Darwin, Design and Dawkins’ Dilemma.” Sophia. Vol. 51. No. 1. 31-57.

Haack, Susan. 2003. Defending science - within reason: between scientism and cynicism. New York, NY: Prometheus Books.

Halvorson, Hans. 2014. "Why Methodological Naturalism?” The Blackwell Companion to Naturalism. Ed. Kelly James Clark. Oxford: Blackwell. Preprint version available at <http://philsciarchive.pitt.edu/11003/1/metnat3.pdf >. Accessed on March 30, 2016.

Hansson, Sven Ove. 2014. "Science and Pseudo-Science". The Stanford Encyclopedia of Philosophy (Spring 2015 Edition). Ed. Edward N. Zalta. Available at <http://plato.stanford.edu/archives/spr2015/entries/pseudo-science/>.

Haught, John. 2008. "Is fine-tuning remarkable?" The fitness of the cosmos for fife: biochemistry and finetuning. Eds John Barrow, Simon Conway-Morris, Stephen Freeland and Charles Harper. Cambridge: Cambridge University Press. 31-48.

Hutchinson, Ian. 2011. Monopolizing knowledge: a scientist refutes religion-denying, reason-destroying scientism. Belmont, MA: Fias Publishing.

Johnson, Philip E. 1993. Darwin on Trial. $2^{\text {nd }}$ ed. Downers Grove, Illinois: InterVarsity Press. 1995. Reason in the Balance. Downers Grove, Illinois: InterVarsity Press.

Jones, John E. 2005 Tammy Kitzmiller, et al. v. Dover Area School District, et al. Memorandum Opinion. Case 4:04-cv-02688-JEJ. Document 342. The United States Disctrict Court for the Middle State of Pennsylvania. Available online at <http://ncse.com/files/pub/legal/kitzmiller/highlights/2005-1220_Kitzmiller_decision.pdf $>$. Accessed on April 22, 2016.

Kelemen, Deborah. 2004. "Are Children 'Intuitive Theists'? Reasoning About Purpose and Design in Nature." Psychological Science. Vol. 15. No. 5. 295-301.

Kitcher, Phillip. 2007. Living With Darwin: Evolution, Design and the Future of Faith. New York: Oxford University Press.

Kojonen, Erkki Vesa Rope. 2016a. The Intelligent Design Debate and the Temptation of Scientism. Routledge Science \& Religion Series. London: Routledge.

Analytic Theology. Vol. 4.

------ forthcoming. "Salvaging the Biological Design Argument in Light of Darwinism?"

Accepted for publication in Theology \& Science. 
Koons, Robert C. 2003. "Science and Theism: Concord, Not Conflict." The Rationality of Theism. Ed. Paul Copan \& Paul K. Moser. London: Routledge.

Koperski, Jeffrey. 2008. "Two Bad Ways to Attack Intelligent Design and Two Good Ones.” Zygon. Vol. 43. No. 2. 433-449.

Labody, Guus. 2015. "A Defense of Partisan Science: An Assessment of Stenmark's Non-Partisan Science." Theology \& Science. Vol. 13. No. 1. 79-88.

Leslie, John. 1989 Universes. London: Routledge.

Luskin, Casey. 2008. "ID Does Not Address Religious Claims About the Supernatural.” Opposing views.com. Available at <http://www.opposingviews.com>. Accessed on May 10, 2013.

Mackie, J. L. 1982. The Miracle of Theism: Arguments For and Against the Existence of God. Oxford: Clarendon.

Manning, Russell Re, Brooke, John Hedley \& Watts, Fraser. 2013. The Oxford Handbook of Natural Theology. Oxford: Oxford University Press.

McCullough, Ross. 2013. "God and the Gaps." First Things. April issue. Available at <http://www.firstthings.com/article/2013/04/god-and-the-gaps>.

McDonald, Patrick \& Tro, Nivaldo J. Forthcoming. "In Defense of Methodological Naturalism." Accepted for publication in Christian Scholar's Review.

McGrath, Alister E. 2002. A Scientific Theology, Vol 2: Reality. Edinburgh: T \& T Clark. 2016. Re-Imagining Nature: The Promise of a Christian Natural Theology. Hoboken:

Wiley.

Meyer, Stephen C. 2009. Signature in the Cell: DNA and the Evidence for Intelligent Design. San Francisco, CA: HarperOne. 1999. "The Scientific Status of Intelligent Design: The Methodological Equivalence of Naturalistic and Non-Naturalistic Origins Theories." Science and Evidence for Design in the Universe. Proceedings of the Wethersfield Institute. Vol. 9. Eds W.A. Dembski and Stephen C. Meyer. San Francisco, CA: Ignatius Press. 151-212.

Monton, Bradley. 2009. Seeking God in Science: An Atheist Defends Intelligent Design. Toronto, ON: Broadview Press.

Murphy, Nancey. 1993. Theology in an Age of Scientific Reasoning. Cornell Studies in the Philosophy of Religion. Ithaca, NY: Cornell University Press.

Nagasawa, Yujin. 2010. The Existence of God: A Philosophical Introduction. New York, NY: Routledge.

Niiniluoto, Ilkka. 2002. Critical Scientific Realism. Oxford: Oxford University Press.

Numbers, Ronald 2003 "Science without God: Natural Laws and Christian Beliefs." When Science and Christianity Meet. Eds. Ronald Numbers \& David C. Linberg. Chicago, IL: University of Chicago Press. 265-286. 
Orr, Allen. 2007. “A Mission to Convert. Review of 'the God Delusion'.” The New York Review of Books. January 11 .

Peacocke, Arthur. 1993. Theology for a Scientific Age: Being and Becoming, Divine and Human. Enlarged edition. Minneapolis, MN: Fortress Press.

Pennock, Robert C. 1999. The Tower of Babel: The Evidence against the New Creationism. Cambridge, MA: MIT Press.

2011. 'Can't Philosophers Tell the Difference Between Science and Religion?

Demarcation Revisited'. Synthese. Vol. 178. No. 2. 177-206.

Pennock, Robert C. \& Ruse, Michael (Eds). 2009. But Is It Science? The Philosophical Question in the Creation/Evolution Controversy. Updated Edition. Amherst, NY: Prometheus Books.

Philipse, Herman. 2012. God in the Age of Science: A Critique of Religious Reason. Oxford: Oxford University Press.

Plantinga, Alvin. 2007. "The Dawkins Confusion: Naturalism ad Absurdum.” Books \& Culture. A Service of Christianity Today. Vol. 13. No. 2.

1997. "Methodological Naturalism? Part 2." Origins \& Design. Vol 18. No. 2. Available

at

<https://www.calvin.edu/academic/philosophy/virtual_library/articles/plantinga_alvin/methodological_natur alism_part_2.pdf>. Accessed on April 21, 2016.

1991. "When Faith and Reason Clash: Evolution and the Bible." Christian Scholar's

Review. Vol. 21. No. 1. 8-32.

Quinn, Philip. 2009. "Creationism, Methodology, and Politics." But is it Science?: The Philosophical Question in the Creation/Evolution Controversy. Eds Robert Pennock and Michael Ruse. Amherst, NY: Prometheus Books. 367-385.

Ratsczh, Del. 2001. Nature, Design and Science: The Status of Design in Natural Science. Albany, NY: State University of New York Press.

2002. "Design Theory and Its Critics: Monologues Passing in the Night. Review Article of: Robert T. Pennock (ed.), Intelligent Design Creationism and its Critics." Ars Disputandi. The Online Journal for Philosophy of Religion. Vol. 2.

353-365.

2004. "Stenmark, Plantinga and Scientific Neutrality." Faith and Philosophy. Vol. 21. No. 3.

Ratszch, Del \& Koperski, Jeffrey. 2015. “Teleological Arguments for God's Existence.” Stanford Encyclopedia of Philosophy. Spring 2015 Edition. Ed. Edward N. Zalta. Available at <http://plato.stanford.edu/archives/spr2015/entries/teleological-arguments/>.

Ritchie, Jack. 2008 Understanding Naturalism. Stocksfield: Acumen.

Ruse, Michael. 2009. "Witness Testimony Sheet: McLean v. Arkansas." 253-278. But Is It Science? The Philosophical Question in the Creation/Evolution Controversy. Updated Edition. Eds. Robert Pennock \& Michael Ruse. Amhurt, NY: Prometheus Books.

1982. Darwinism Defended. Reading, Mass: Addison-Wesley.

Russell, Robert J. 2005. "Intelligent Design is Not Science and Does Not Qualify to be Taught in Public School Science Classes." Theology and Science. Vol. 3. No. 2. 131-132. 
2008. Cosmology from Alpha to Omega: The Creative Mutual Interaction of Theology and Science. Minneapolis, MN: Fortress Press.

Sarkar, Sahotra. 2011. “The Science Question in Intelligent Design.” Synthese. Vol. 178. No. 2. 291-305.

Shanks, Niall. 2004. God, the Devil and Darwin: A Critique of Intelligent Design Theory. Oxford: Oxford University Press.

Silva, Ignacio. 2014. "Great Minds Think (Almost) Alike: Thomas Aquinas and Alvin Plantinga on Divine Action in Nature." Philosophia Reformata. Vol. 79. No. 1. 8-20.

Sollereder, Bethany. 2015. "A Modest Objection: Neo-Thomism and God as a Cause among Causes." Theology and Science. Vol. 13. No. 3. 345-353.

Sober, Elliott. 2007. "Intelligent Design and the Supernatural: The "God of the Extraterrestrials" Reply." Faith and Philosophy. Vol. 24. No. 1. 72-82.

Stenmark, Mikael. 2001. Scientism: Science, Ethics and Religion. Burlington: Ashgate Publishing Co. 2004. How to Relate Science and Religion: A Multi-Dimensional Model. Grand Rapids, MI: Wm. B. Eerdmans Publishing Co.

Swinburne, Richard. 2004. The existence of God. Oxford: Oxford University Press.

Taylor, Charles. 2005. "Geschlossene Weltstrukture in der Moderne." Wissen und Weisheit: Zwei Symposien zu Ehre von Josep Pieter. Ed. Hermann Fechtrup, Friedbert Schulze \& Thomas Sternberg. 137169. Münster: LIT Verlag.

Thaxton, Charles, Bradley, Walter and Olson, Roger. 1984. The Mystery of Life's Origin: Reassessing Current Theories. Dallas, TX: Lewis and Stanley.

Todd, Scott C. 1999. “A View from Kansas on That Evolution Debate.” Nature. Vol. 401. 423.

Ylikoski, Petri. 2001. Understanding Interests and Causal Explanations. Helsinki: University of Helsinki. Vainio, Olli-Pekka. 2010 Beyond Fideism: Negotiable Religious Identities. Burlington, VT: Ashgate.

Wahlberg, Mats. 2012. Reshaping Natural Theology: Seeing Nature as Creation. London: Palgrave Macmillan.

Williams, Richard N. \& Robinson, Daniel N. Ed. 2014. Scientism: The New Orthodoxy. New York, NY: Bloomsbury Academic. 